Yüksel Büşra Yüksel Aykanat ${ }^{1}$

Research Asst., Department of Early Childhood Education, Erciyes University

Kayseri, Turkey

UDC: 37.018 .262

Esra Ömeroğlu ${ }^{2}$

DOI: $10.5937 /$ IstrPed2102511Y

Prof. Dr., Department of Early Childhood Education, Gazi University

Ankara, Turkey

\title{
THE PARENT-CHILD COMMUNICATION DURING THE COURSE OF COVID-19 PANDEMIC
}

\begin{abstract}
Due to Covid-19, which emerged in 2019 and had an impact all over the world, many people started working from home and schools started to provide distance education. Therefore, parents had to spend more time at home with their children. Hence, communication between parents and children at home has become even more important. This study aims to examine the communication of parents with children in the preschool period at home during the covid-19 pandemic period with their children. In this context, relational research model, one of the quantitative research methods, was used in the research. Data was gathered in Turkey in 2020, from forty-eight seventy-two-month-old children and from 146 mothers/fathers. Demographic information form and "Parent-Child Communication Assessment Tool" were used to collect data. The measurement tool was delivered to the participants in the form of an online link and they were asked to fill in, taking into account their communication with their children during the pandemic period. The data were analyzed and it was observed that the communication of the children at home with their parents differs according to their preschool education status, the number of siblings and the educational level of the father, but not according to the education level of the mother.
\end{abstract}

Keywords: early childhood, Covid-19, parent-child communication.

\section{Introduction}

The Covid-19 epidemic, which broke out in December 2019 and affected the whole world, was declared a pandemic by the World Health Organization, and it was reported that the virus spread to many countries (WHO, 2020). Most of the countries took measures in order to stop the spread of the epidemic such as "social distancing", and as a result of these measures, faceto-face education was suspended in a lot of schools (Dalton, Rapa, \& Stein, 2020; Lancker \& Parolin, 2020). Due to the closure of schools and preventive lockdowns, children had to spend most of their time at home, and their peer interactions were reduced to the minimum level (Jiao, et al., 2020). Consequently, the communication of children with their parents at home became more important (United Nations Children's Fund, 2020). It was observed that the conception of this process differs for each age group. As a result of the lockdowns, parents started to work from home and spend more time with their children. Therefore, the communication between parents and children became more critical. Staying at home for a long time and away from their peers emerged as a source of stress.

The mental, social, emotional and biological well-being of children can be significantly and permanently affected by stressful situations and environments (Lieberman, 2011; Cohen \& 
Scheeringa, 2009). The capability of children to protect themselves from sources of stress in stressful times substantially depends on emotional states of parents (Bariola, Gullone, \& Hughes, 2019). Parents can utilize effective strategies to deal with children's state of stress. These strategies can affect the reactions of children to the states of stress; however, the conditions mediating the relationship between stress and reaction of children need to be investigated more (Crnic, Gaze, \& Hoffman, 2005; Pat-Horenczyk, et al., 2015). One of the factors affecting this relationship is the communication of parents with children. Communication is a process which progresses as effective-ineffective, positive-negative and conscious-unconscious exchange of messages (Zolten \& Long, 2006). The effect of family on children is immense during the early childhood period. Parent-child interaction and communication must be of high-quality in this period (Alkhateeb \& Wardat, 2017). The family circle and early communication experiences of children, the roles adopted by parents towards a child and the experiences of children with their parents have relationship, academic and behavioral impacts on them (Levin \& Currie, 2010; O'Boyle, 2012). Attentive attitudes of parents toward their children and building the children's expectations in accordance with the physical, emotional and social capacities and skills of their children contribute to the emotional, physical and social aspects of a child. Thanks to the adult-child interaction, many skills can be learned during early childhood period (Cox \& Leaper, 1961; Dodici, Draper, \& Peterson, 2003).

Conducted researches indicate that a supportive, interactive and warm family-child relationship can be related to social, cognitive and linguistic competences of children (NICHD, 1999). Furthermore, it is stated that there is a relationship between the family-child communication during early childhood period and the future levels of satisfaction with life, stress and anxiety of a child (Levin \& Currie, 2010). A number of environments and conditions such as the society in which the child lives, school, experienced political alterations and disasters are influential on the development of a child. Experienced changes can also have effects on communication and interaction within a family (Trawick-Smith, 2014).

Today, parents are in active work life while children are at school. Due to the limitations experienced during the pandemic, parents and children started to spend more time together, not just in their spare time after work and school, as they stayed at home throughout the day. This situation led to more communication between parents and children. During and after a crisis, parents need to plan strategies to develop and strengthen their communication with their children on a more sound basis. Moreover, during the current period when numerous things such as education, meetings and information exchange are administered remotely, the net based on digital collaboration is crucial. Therefore, this study is critical to reveal the current situation of parent and child communication during the Covid-19 pandemic and guide parents for communication. This study aims to examine the parent-child communication during the Covid-19 pandemic for children in the early childhood period. In accordance with this purpose, answers to the following questions were sought:

During the pandemic,

1. Does the parent-child communication at home differ according to the preschool education status of a child?

2. Does the parent-child communication differ according to the number of siblings of a child?

3. Does the parent-child communication differ according to the educational background of the mother?

4. Does the parent-child communication differ according to the educational background of the father? 


\section{Method}

Participants of the study, data collection and data analysis are discussed in this section.

Due to factors such as the closure of schools and adopting flexible working hours during the pandemic, children and parents started to spend more time together. As a result of this, their communication with each other became more important relative to the period before the endemic. Correlational survey model among the quantitative research designs was employed in order to gather information regarding the variables which can have a role in the communication of parents with their children during this period such as receiving preschool education, the number of siblings, mother's educational background and father's educational background. It is aimed to reveal the statistical relationship between more than one variable measured in this model (Gorard, 2004; Singh, 2007). The dependent variable is parent-child communication, and the independent variables are the state of receiving preschool education of the child, the number of siblings and the educational backgrounds of the mother and father.

\section{Data Collection}

In order to show the personal information of parents and children, a personal information form including details about age, gender, status of receiving preschool education, the number of siblings of children and the educational backgrounds of parents was employed. In order to evaluate the communication of parents with their children between the ages of forty-eight and seventy-two months, the "Parent-Child Communication Assessment Tool (PCCAT)" developed by Arabaci (2011) was used and tested for validity and reliability. The scale is a 37-item five-point likert tool with five subscales of speaking, listening, message, non-verbal communication and empathy. The assessment tool was filled in by parents. The assessment tool is composed of 8 items for the speaking subscale, 6 items for the listening subscale, 8 items for the message subscale, 6 items for the non-verbal communication subscale and 9 items for the empathy subscale. Parents mark the option which best describes them from the "always, very often, sometimes, rarely, never" options to rate their communication with their children. Each item corresponds to 5, 4, 3, 2 and 1 points, respectively, and a total score is obtained for each subscale. The validity and reliability research for the assessment tool was conducted among 801 parents with children between the ages of forty-eight and seventy-two that receiving preschool education. The scale, which was originally composed of 86 items, took its final 37-item form after the validity and reliability research. The Cronbach Alpha reliability analysis coefficients were found as 0.67 for the Speaking subscale, 0.70 for the Listening subscale, 0.60 for the message subscale, 0.56 for the Non-verbal communication subscale and 0.73 for the empathy subscale. The test-retest correlations were identified as 0.93 for the Speaking subscale, 0.96 for the Listening subscale, 0.98 for the message subscale, 0.95 for the Non-verbal communication subscale and 0.96 for the Empathy subscale (Arabaci, 2011).

After the necessary permission for ethics was obtained from the Ministry of Health, the text explaining the purpose of this study due to the pandemic the world is going through, the personal information form and "The Parent-Child Communication Assessment Tool" were issued as online documents. The link for the document was shared online across Turkey, and mothers or fathers with children between the ages of forty-eight and seventy-two months were invited to fill them in. 


\section{Study Group}

In the study, parents with children between the ages of forty-eight and seventy-two months were invited to participate in the study and fill in the online document. The Nunnanly sample size determination method was chosen to determine the number of samples. According to this, the number of samples is recommended to be 5 times as many as the number of items in the assessment tool (Nunnanly \& Bernstein, 1984). The utilized "Parent-Child Communication Assessment Tool (PCCAT)" is consisted of 37 items. Accordingly, the number of samples must be 185 . In this research, 220 people were reached out to; however, the number of samples was reduced to 146 due to data loss. The children are $39.7 \%$ male, $60.7 \%$ female, $30.1 \%$ between the age of 40 and 60 months, and $69.9 \%$ between the ages of 61 and 72 months. It was observed that $78.8 \%$ are receiving preschool education while $21.2 \%$ aren't, and $27.4 \%$ are only child while $61.6 \%$ have one or two and $11.0 \%$ have three or above siblings. Their mothers are $35.6 \%$ primary, secondary or high school graduates, $53.4 \%$ with a bachelor's degree and $11 \%$ with a master's degree while their fathers are $39.7 \%$ primary, secondary or high school graduates, $48.6 \%$ with a bachelor's degree and $11.6 \%$ with a master's degree.

\section{Data Analysis}

Firstly, the reliability of the assessment tool was tested for data analysis. Cronbach's Alpha value was calculated $(\alpha=.775)$ for this purpose. T-Test was conducted to reveal the relationship between the status of being received preschool education and their communications with parents, and ANOVA and Kruskal Wallis tests were carried out to show the relationship of the number of siblings and educational backgrounds of parents with communication.

\section{Findings}

This section includes the findings regarding the relationship of the speaking, listening, message, non-verbal communication and empathy subscales and communication with variables in this study aiming to investigate parent-child communication during the Covid-19 pandemic.

Table 1. The Parent-Child Communication Assessment Tool (PCCAT) T-Test Results regarding the Subscale Scores for Children's Status of Receiving Preschool Education

\begin{tabular}{|c|c|c|c|c|c|c|}
\hline Subscales & $\begin{array}{c}\text { State of Receiving preschool } \\
\text { education }\end{array}$ & $n$ & $x$ & sd & $t$ & $p$ \\
\hline \multirow[t]{2}{*}{ Listening } & Do & 115 & 26.33 & 2.81 & \multirow[b]{2}{*}{.021} & \multirow[b]{2}{*}{.984} \\
\hline & Don't & 31 & 26.32 & 4.18 & & \\
\hline \multirow[t]{2}{*}{ Message } & Do & 115 & 26.59 & 3.39 & \multirow[b]{2}{*}{2.276} & \multirow[b]{2}{*}{.026} \\
\hline & Don't & 31 & 25.41 & 2.26 & & \\
\hline \multirow{2}{*}{$\begin{array}{l}\text { Non-verbal } \\
\text { Communication }\end{array}$} & Do & 115 & 20.77 & 1.86 & \multirow[b]{2}{*}{2.321} & \multirow[b]{2}{*}{.022} \\
\hline & Don't & 31 & 19.90 & 1.79 & & \\
\hline \multirow[t]{2}{*}{ Empathy } & Do & 115 & 38.71 & 4.11 & \multirow[b]{2}{*}{3.216} & \multirow[b]{2}{*}{.003} \\
\hline & Don't & 31 & 35.29 & 5.52 & & \\
\hline \multirow[t]{2}{*}{ Total } & Do & 115 & 146.65 & 11.21 & \multirow[b]{2}{*}{2.672} & \multirow[b]{2}{*}{.011} \\
\hline & Don't & 31 & 139.45 & 13.82 & & \\
\hline
\end{tabular}

$\mathrm{n}=$ sample size, $\mathrm{x}=$ mean, $\mathrm{sd}=$ standard deviation, $\mathrm{t}=$ independent samples $\mathrm{T}$ Test, $\mathrm{p}=$ significance

As seen Table 1, no significant difference was identified between children's status of receiving preschool education and listening subscale ( $p>.05)$, a positive relationship was observed between the message, non-verbal communication and empathy subscales and receiving 
preschool education ( $p<.05$ ). For the speaking subscale, on the other hand, Mann Whitney $U$ Test was conducted, and no significant difference was revealed between speaking and a child's status of receiving preschool education ( $p=.059)$. The total score indicates a difference in the communication of children with their parents according to their status of receiving preschool education $(\mathrm{p}<.05)$.

Table 2. The Parent-Child Communication Assessment Tool (PCCAT) ANOVA Results regarding the Subscale Scores for the Number of Children's Siblings

\begin{tabular}{|c|c|c|c|c|c|c|}
\hline Subscales & Number of Siblings & $\mathbf{N}$ & $\mathbf{x}$ & sd & 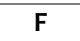 & $\mathbf{p}$ \\
\hline \multirow[t]{3}{*}{ Message } & Only child & 40 & 26.65 & 2.70 & \multirow{3}{*}{.256} & \multirow{3}{*}{.774} \\
\hline & 1 or 2 siblings & 90 & 26.21 & 3.35 & & \\
\hline & 3 or above siblings & 16 & 26.31 & 3.70 & & \\
\hline \multirow[t]{3}{*}{ Empathy } & Only child & 40 & 39.50 & 4.09 & \multirow{3}{*}{4.723} & \multirow{3}{*}{.010} \\
\hline & 1 or 2 siblings & 90 & 37.07 & 4.73 & & \\
\hline & 3 or above siblings & 16 & $39 \cdot 31$ & 4.36 & & \\
\hline
\end{tabular}

$\mathrm{n}=$ sample size, $\mathrm{x}=$ mean, $\mathrm{sd}=$ standard deviation, $\mathrm{F}=$ frequency, $\mathrm{p}=$ significance

Table 3. The Parent-Child Communication Assessment Tool (PCCAT) Kruskal Wallis Test Results regarding the Subscale Scores for the Number of Children's Siblings

\begin{tabular}{|c|c|c|c|c|c|c|}
\hline Subscales & Number of Siblings & $\mathbf{n}$ & Mean rank & sd & $\mathrm{X}^{2}$ & $\mathrm{p}$ \\
\hline \multirow[t]{3}{*}{ Speaking } & Only child & 40 & 86.75 & \multirow{3}{*}{2} & \multirow{3}{*}{8.41} & \multirow{3}{*}{.015} \\
\hline & 1 or 2 siblings & 90 & 65.53 & & & \\
\hline & 3 or above siblings & 16 & 85.19 & & & \\
\hline \multirow[t]{3}{*}{ Listening } & Only child & 40 & 89.06 & \multirow{3}{*}{2} & \multirow{3}{*}{11.36} & \multirow{3}{*}{.003} \\
\hline & 1 or 2 siblings & 90 & $64 \cdot 30$ & & & \\
\hline & 3 or above siblings & 16 & 86.34 & & & \\
\hline \multirow{3}{*}{$\begin{array}{l}\text { Non-verbal } \\
\text { Communication }\end{array}$} & Only child & 40 & 87.74 & \multirow{3}{*}{2} & \multirow{3}{*}{7.82} & \multirow{3}{*}{.020} \\
\hline & 1 or 2 siblings & 90 & 66.17 & & & \\
\hline & 3 or above siblings & 16 & 79.13 & & & \\
\hline \multirow[t]{3}{*}{ Total } & Only child & 40 & 91.06 & \multirow{3}{*}{2} & \multirow{3}{*}{13.19} & \multirow{3}{*}{.001} \\
\hline & 1 or 2 siblings & 90 & 63.55 & & & \\
\hline & 3 or above siblings & 16 & 85.56 & & & \\
\hline
\end{tabular}

$\mathrm{n}=$ sample size, $\mathrm{x}=$ mean, $\mathrm{sd}=$ standard deviation, $\mathbf{X}^{2}=$ Kruskal Wallis Test, $\mathrm{p}=$ significance

Based on the normality distribution of the subscale of the number of siblings, ANOVA test was carried out as it was normally distributed to the message and empathy subscales, and the Kruskal Wallis test was conducted as the speaking, listening and non-verbal communication subscales were non-normally distributed to the total score. Accordingly, a significant difference in favour of the only child was concluded for the empathy subscale in Table $2(p<.05)$. Examining the relationship between the number of children's siblings and their relationship with their families in Table 3, significant differences in favour of only child for the speaking, listening and non-verbal communication subscales are demonstrated $(p<.05)$. Furthermore, the total score also indicates a conclusion in favour of only child for parent and child communication $(p<.05)$.

Table 4. The Parent-Child Communication Assessment Tool (PCCAT) ANOVA Test Results regarding the Subscale Scores for the Educational Background of the Mother

\begin{tabular}{lcccccc}
\hline Subscales & Educational background & N & X & sd & F & P \\
\hline Speaking & Primary, secondary or high school & 52 & 33.38 & 5.13 & & \\
\cline { 2 - 5 } & Bachelor's degree & 78 & 34.15 & 3.32 & & \\
\cline { 2 - 5 } & Master's degree & 16 & 34.06 & 2.79 & .591 & \multirow{2}{*}{.555} \\
\hline Listening & Primary, secondary or high school & 52 & 26.00 & 4.07 & & \\
\cline { 2 - 5 } & Bachelor's degree & 78 & 26.55 & 2.48 & \\
\hline
\end{tabular}




\begin{tabular}{|c|c|c|c|c|c|c|}
\hline & Master's degree & 16 & 26.37 & 2.50 & .479 & .620 \\
\hline \multirow[t]{3}{*}{ Message } & Primary, secondary or high school & 52 & 26.03 & 3.48 & & \\
\hline & Bachelor's degree & 78 & 26.53 & 2.81 & & \\
\hline & Master's degree & 16 & 26.37 & 4.16 & .375 & .688 \\
\hline \multirow{3}{*}{$\begin{array}{l}\text { Non-verbal } \\
\text { Communication }\end{array}$} & Primary, secondary or high school & 52 & 20.25 & 1.81 & & \\
\hline & Bachelor's degree & 78 & 20.91 & 1.87 & & \\
\hline & Master's degree & 16 & 20.12 & 1.96 & 2.519 & .084 \\
\hline \multirow[t]{3}{*}{ Empathy } & Primary, secondary or high school & 52 & 37.53 & 5.64 & & \\
\hline & Bachelor's degree & 78 & 38.32 & 4.12 & & \\
\hline & Master's degree & 16 & 37.81 & 3.42 & .451 & .638 \\
\hline \multirow[t]{3}{*}{ Total } & Primary, secondary or high school & 52 & 143.21 & 15.48 & & \\
\hline & Bachelor's degree & 78 & 146.47 & 9.92 & & \\
\hline & Master's degree & 16 & 144.75 & 8.85 & 1.139 & .323 \\
\hline
\end{tabular}

$\mathrm{n}=$ sample size, $\mathrm{x}=$ mean, $\mathrm{sd}=$ standard deviation, $\mathrm{F}=$ frequency, $\mathrm{p}=$ significance

Table 4. The Parent-Child Communication Assessment Tool (PCCAT) ANOVA Test Results regarding the Subscale Scores for the Educational Background of the Father

\begin{tabular}{|c|c|c|c|c|c|c|}
\hline Subscales & Educational background & $\mathbf{N}$ & $\mathbf{x}$ & sd & $\mathbf{F}$ & $\mathbf{p}$ \\
\hline \multirow[t]{3}{*}{ Listening } & Primary, secondary or high school & 58 & 25.72 & 3.84 & \multirow[b]{3}{*}{2.789} & \multirow[b]{3}{*}{.065} \\
\hline & Bachelor's degree & 71 & 26.95 & 2.50 & & \\
\hline & Master's degree & 17 & 25.82 & 2.40 & & \\
\hline \multirow{3}{*}{$\begin{array}{l}\text { Non-verbal } \\
\text { Communication }\end{array}$} & Primary, secondary or high school & 58 & 20.22 & 1.77 & \multirow[b]{3}{*}{3.953} & \multirow[b]{3}{*}{.021} \\
\hline & Bachelor's degree & 71 & 20.63 & 1.89 & & \\
\hline & Master's degree & 17 & 21.64 & 1.83 & & \\
\hline \multirow[t]{3}{*}{ Empathy } & Primary, secondary or high school & 58 & 37.18 & 5.11 & \multirow[t]{3}{*}{1,500} & \multirow[t]{3}{*}{.227} \\
\hline & Bachelor's degree & 71 & 38.60 & 4.41 & & \\
\hline & Master's degree & 17 & 38.11 & 3.65 & & \\
\hline
\end{tabular}

$\mathrm{n}=$ sample size, $\mathrm{x}=$ mean, sd=standard deviation, $\mathrm{F}=$ frequency, $\mathrm{p}=$ significance

Table 5. The Parent-Child Communication Assessment Tool (PCCAT) Kruskal Wallis Test Results regarding the Subscale Scores for the Educational Background of the Father

\begin{tabular}{|c|c|c|c|c|c|c|}
\hline Subscales & Educational background & $\mathbf{N}$ & Mean rank & sd & $\mathrm{X}^{2}$ & $\mathbf{p}$ \\
\hline \multirow[t]{3}{*}{ Speaking } & Primary, secondary or high school & 58 & 67.10 & \multirow{3}{*}{2} & \multirow{3}{*}{2.497} & \multirow{3}{*}{.287} \\
\hline & Bachelor's degree & 71 & 78.87 & & & \\
\hline & Master's degree & 17 & 72.88 & & & \\
\hline \multirow[t]{3}{*}{ Message } & Primary, secondary or high school & 58 & 65.47 & \multirow{3}{*}{2} & \multirow{3}{*}{6.452} & \multirow{3}{*}{.040} \\
\hline & Bachelor's degree & 71 & 82.55 & & & \\
\hline & Master's degree & 17 & 63.09 & & & \\
\hline \multirow[t]{3}{*}{ Total } & Primary, secondary or high school & 58 & 63.52 & \multirow{3}{*}{2} & \multirow{3}{*}{6.498} & \multirow{3}{*}{.039} \\
\hline & Bachelor's degree & 71 & 82.42 & & & \\
\hline & Master's degree & 17 & 70.29 & & & \\
\hline
\end{tabular}

$\mathrm{n}=$ sample size, $\mathrm{x}=$ mean, $\mathrm{sd}=$ standard deviation, $\mathrm{X}^{2}=$ Kruskal Wallis Test, $\mathrm{p}=$ significance

Based on the normality distribution of the subscale of educational background of the father, ANOVA test was carried out as it was normally distributed to the listening, non-verbal communication and empathy subscales, and the Kruskal Wallis test was conducted as the speaking and message subscales were non-normally distributed to the total score.

Table 4, on the other hand, demonstrates that there is no significant difference between the educational background of fathers and the subscales of listening $(p=.065)$ and empathy $(p=.227)$, and there is a significant difference for the non-verbal communication subscale $(p=.021)$ which is in favour of fathers with a master's degree. 
Table 5 reveals that there is no significant difference between the educational background of fathers and the speaking subscale $(p=.287)$ while there is a significant difference for the message subscale $(p=.04)$ in favour of fathers with a bachelor's degree among primary, secondary or high school graduate fathers and fathers with a bachelor's degree. Furthermore, a significant difference in favour of fathers with a bachelor's degree stands out considering the total score.

\section{Conclusion and Discussion}

In this study, it was aimed to investigate the communication of children between the ages of forty-eight and seventy-two months with their parents during the Covid-19 pandemic. This study concludes that children's communication with their parents exhibits difference regarding the status of receiving preschool education, number of siblings and educational background of fathers while it does not regarding the educational background of mothers.

Examining children's status of receiving preschool education, it is observed that the preschoolers have more positive communication with their parents compared to the ones who are not. In addition to this, results indicate that preschoolers are more advantageous for the non-verbal communication and empathy subscales. Looking into previous studies, it has been seen that the Covid-19 pandemic can lead to a wide range of stress factors such as the pandemic being an unpredictable situation and its indefinite duration, risk of infection, lack of face-to-face interaction with classmates and teachers and lack/scarcity of place (Brooks, et al., 2020; Liu, Bao, Huang, Shi, \& Lu, 2020). Preschoolers can be more successful in dealing with these stress factors. Because, at school, they can become efficient in comprehension of messages received from their teachers and friends, getting along with their friends in plays by means of non-verbal communication and empathize with circumstances/situations faced in the classroom environment. Furthermore, the idea of getting back together with their teachers and friends at the end of the pandemic period can reduce the sources of stress and, thus, make them more open to communication (Chen, Chang, He, \& Liu, 2005; Gerrits, Goudena, \& van Aken 2005). Another reason for getting significant differences for the status of receiving preschool education in the subscales of message, non-verbal communication and empathy can be that children comprehend reflections of emotions and thoughts of their teachers and friends and provide feedback in classroom. In classroom environment, children can easily convey their emotions and thoughts in activities they are involved in (Pasiak, 2011). For example, they can communicate that they get upset or angry with their gestures and facial expressions when a toy is taken from them while they are playing, and they can understand others' expressions. Reflections of these skills can be observed at home towards their parents. They can comprehend the messages from their parents based on their experiences at school and communicate with them non-verbally. Shorer and Leibovich (2020) pointed out in their study that if children spend more time playing games in times of crisis, this reduces stress reactions and calms them. It is reckoned that the reason for the better communication of the preschoolers with their parents can be the game initiation and maintenance skills attained at school. In another research, it is reported that children had to stay at home for long times due to the closure of schools, and that led to limited communication with their classmates and a decrease in physical activities (Jiao, et al., 2020). Children actively going to preschool are in communication with their peers, and this communication becomes their daily routine. Because of the closure of schools, children may have the desire to keep up this communication and so satisfy their need for communication with their parents. This can be interpreted as one of the reasons for the better communication of preschool children with their parents in this study. 
In a prestudy conducted with collaboration of China, The European Pediatric Association (EPA) and the Union of National European Pediatric Societies and Associations (UNEPSA), it was recorded that children between the ages of 3 and 6 are more afraid of the possibility of family members to contract the disease and more clinging to their families during this period (Jiao, et al., 2020). It has been suspected that, in accordance with this, the anxiety levels of children have increased, and so they have become more clinging to family members in our country too. Parents may also feel the need to spend more time with their children in order to soothe them. The reason for parent-child communication being in favour of only children may be related to the fact that parents of only children have more time to allocate for their children. Moreover, parents spend their times in activities with their children during the epidemic period, and the reason for the fact that only children have better communication with their parents than children with siblings can be interpreted as the concentration of communication for only one child.

Bubb and Jones (2020) reported in their study that families are more participative in the learning process of children at home, get more information about them than before and play a more important role for children's education. Accordingly, families focusing on only children can be the reason for the higher scores in favour of only child. It can be harder for parents with children at various learning stages to monitor their children and satisfy their needs quickly compared to parents with an only child.

It has been seen that, in the quarantine period, calmness of family members and parents speaking with them about the situation make it easier for children to deal with isolation (Orgiles et al., 2020). In accordance with this, it can be considered that the higher scores of fathers with a bachelor's or master's degree for message and non-verbal communication subscales are caused by their higher-level awareness of the need for communication with children in order to inform and comfort them. Furthermore, these fathers may have better financial conditions and lesser or no financial worries compared to fathers of other education levels. Since this situation does not lead to a source of stress for the father, it can affect the child positively to take this as a message and not to see her/his father worried. It has been reported that perceptual skills develop in early childhood and adolescence periods. It is quite critical to have sensitive and effective communication with children about significantly life-threatening and affecting diseases such as Covid-19 for the wellbeing of children and families in the long term (Dalton, Rapa, \& Stein, 2020). This study suggests that fathers with a bachelor's or master's degree are more sensitive with communication with their children. This situation is consistent with the statements of Dalton, Rapa and Stein (2020).

Taking the conclusions and limitations of the study into consideration, the followings can be recommended to parents and researchers:

- It can be suggested that researchers should conduct studies with larger study groups, longer-term studies, longitudinal studies and studies addressing relationship of children with their teachers and peers.

- Long term effects of the pandemic period can be studied with different age groups.

- Children can be provided with opportunities to express their emotions in order to ensure that they express themselves during this period. As can be observed in the study, parent-child communication embodies not only speaking but also other skills such as non-verbal communication, empathy and message. Families must take these circumstances into consideration. 


\section{References}

Alkhateeb, O., \& Wardat, M. (2017). The Informative and Referential Pragmatic Function in Parent-Child Interactions in Jordan. US-China Foreign Language, 15(6): 392- 403. 10.17265/1539-8080/2017.06.005

Arabaci, N. (2011). Anne-baba-cocuk iletisimini degerlendirme araci'nin (ABCIDA) gelistirilmesi ve anne-baba- cocuk iletisiminin bazi degiskenler acisindan incelenmesi. (Publication no: 298409) [Doctoral dissertation, Gazi Universitesi]. https://tez.yok.gov.tr/UlusalTezMerkezi/tezSorguSonucYeni.jsp

Bariola, E., Gullone, E., \& Hughes, E. K. (2011). Child and adolescent emotion regulation: The role of parental emotion regulation and expression. Clinical Child and Family Psychology Review, 14(2):198- 212. https://doi.org/10.1007/s10567-011-0092-5

Brooks, S. K., Webster, R. K., Smith, L. E., Woodland, L., Wessely, S., Greenberg, N., Rubin, G. J. (2020). The psychological impact of quarantine and how to reduce it: rapid review of the evidence. The lancet, 395(10227): 912-920. https://doi.org/10.1016/S0140$6736(20) 30460-8$

Bubb, S., \& Jones, M. A. (2020). Learning from the COVID-19 home-schooling experience: Listening to pupils, parents/carers and teachers. Improving Schools, 23(3): 209-222. https://doi.org/10.1177\%2F1365480220958797

Chen, X., Chang, L., He, Y., \& Liu, H. (2005). The peer group as a context: Moderating effects on relations between maternal parenting and social and school adjustment in Chinese children. Child Development, 76(2), 417-434. https://doi.org/10.1111/j.14678624.2005.00854.x

Cohen, J. A., \& Scheeringa, M. S. (2009). Post-traumatic stress disorder diagnosis in children: Challenges and promises. Dialogues in Clinical Neuroscience, 11(1): 9. https://dx.doi.org/10.31887\%2FDCNS.2009.11.1\%2Fjacohen

Cox, F. N., \& Leaper, P. M. (1961). Assessing some aspects of the parent-child relationship. Child development, 637-649. https://doi.org/10.2307/1126552

Crnic, K. A., Gaze, C., \& Hoffman, C. (2005). Cumulative parenting stress across the preschool period: Relations to maternal parenting and child behaviour at age 5. Infant and Child Development: An International Journal of Research and Practice, 14(2), 117-132. https://doi.org/10.1002/icd.384

Dalton, L., Rapa, E., \& Stein, A. (2020). Protecting the psychological health of children through effective communication about COVID-19. The Lancet Child \& Adolescent Health, 4(5), 346-347. https://doi.org/10.1016/S2352-4642(20)30097-3

Dodici, B. J., Draper, D. C., \& Peterson, C. A. (2003). Early parent-child interactions and early literacy development. Topics in Early Childhood Special Education, 23(3), 124-36. https://psycnet.apa.org/doi/10.1177/02711214030230030301

Gerrits, M. H., Goudena, P. P., \& van Aken, M. A. (2005). Child-parent and child-peer interaction: Observational similarities and differences at age seven. Infant and Child Development, 14(3), 229-241. https://doi.org/10.1002/icd.377

Gorard, S. (2004). Quantitative Methods in Social Science. Continuum: New York.

Jiao, W. Y., Wang, L. N., Liu, J., Fang, S. F., Jiao, F. Y., Pettoello-Mantovani, M., \& Somekh, E. (2020). Behavioral and emotional disorders in children during the COVID-19 epidemic. The journal of Pediatrics, 221, 264. https://dx.doi.org/10.1016\%2Fj.jpeds.2020.03.013

Lancker, W., \& Parolin, Z. (2020). COVID-19, school closures, and child poverty: a social crisis in the making. The Lancet Public Health, 5(5), e243-e244. https://doi.org/10.1016/S2468$2667(20) 30084-0$ 
Levin, K. A., \& Currie, C. (2010). Family structure, mother child communication, father child communication, and adolescent life satisfaction. Health Education. 10.1108/09654281011038831

Lieberman, A. F. (2011). Infants remember: War exposure, trauma, and attachment in young children and their mothers. Journal of the American Academy of Child and Adolescent Psychiatry, 50(7), 640-641. 10.1016/j.jaac.2011.04.009

Liu, J. J., Bao, Y., Huang, X., Shi, J., \& Lu, L. (2020). Mental health considerations for children quarantined because of COVID-19. The Lancet Child \& Adolescent Health, 4(5), 347-49. https://doi.org/10.1016/S2352-4642(20)30096-1

NICHD Early Child Care Research Network. Child care and mother-child interaction in the first 3 years of life. NICHD Early Child Care Research Network. (1999). Developmental psychology, 35(6), 1399-1413.

Nunnally, J. C., \& Bernstein, I. H. (1994). Psychometric theory (3rd ed.). New York, NY: McGrawHill.

O'Boyle, M. M. (2012). Young children's perspectives on parent-child relationship quality as measured by the berkeley puppet interview: Associations with behavioral adjustment (Order No. 1531791). Available from ProQuest Dissertations \& Theses Global. (1283120336). Retrieved from https://search.proquest.com/dissertationstheses/young-childrens-perspectives-on-parent-child/docview/1283120336/se2?accountid $=15875$

Orgilés, M., Morales, A., Delvecchio, E., Francisco, R., Mazzeschi, C., Pedro, M., \& Espada, J. P. (2021). Coping behaviors and psychological disturbances in youth affected by the COVID-19 health crisis. Frontiers in Psychology, 12, 845 https://doi.org/10.3389/fpsyg.2021.565657

Pasiak, C. (2011). The Effect of Mother-Child Interactional Synchrony: Implications for Preschool Aggression and Social Competence.Electronic Theses and Dissertations. 46. https://scholar.uwindsor.ca/etd/46

Pat-Horenczyk, R., Cohen, S., Ziv, Y., Achituv, M., Asulin-Peretz, L., Blanchard, T. R., ... \& Brom, D. (2015). Emotion regulation in mothers and young children faced with trauma. Infant mental health journal, 36(3), 337-348. https://doi.org/10.1002/imhj.21515

Shorer, M., \& Leibovich, L. (2020). Young children's emotional stress reactions during the COVID-19 outbreak and their associations with parental emotion regulation and parental playfulness. Early Child Development and Care, 1-11. https://doi.org/10.1080/03004430.2020.1806830

Singh, K. (2007). Quantıtatıve socıal research methods. Sage Publication. New Delhi.

Trawick- Smith, J. (2014). Erken cocukluk doneminde gelisim (cok kulturlu bir bakis acisi). Akman, B. (Trans. Ed.). Ankara: Nobel Akademik Yayincilik Egitim Danismanlik.

United Nations Children's Fund. (2020). Interim Guidance for Covid-19 prevention and control in schools. Available at: https://files.eric.ed.gov/fulltext/ED604378.pdf

Zolten, K., \& Long, N. (2006). Parent/child communication. Department of Pediatrics, University of Arkansas for Medical Science.

WHO (2020). Coronavirus disease (COVID-19) advice for the public. Available at: https://www.who.int/news-room/campaigns/connecting-the-world-to-combatcoronavirus/healthyathome/healthyathome---healthy-parenting (Accessed: November) 


\section{Biographical notes:}

Yüksel Büșra YÜKSEL AYKANAT completed her master at Gazi University Department of Early Childhood Education. She is Ph.D candidate at Anadolu University, Department of Early Childhood Education and working as a research assistant at Erciyes University, Department of Early Childhood Education.

Esra ÖMEROĞLU completed both her master and Ph.D degrees in Hacettepe University. She is professor at Gazi University, Faculty of Education, Department of Early Childhood Education since 1998. 